\title{
PENGARUH PENDEKATAN PEMBELAJARAN BAHASA INGGRIS DAN BERHITUNG BERBASIS KEWIRAUSAHAAN TERHADAP PENINGKATAN MINAT BERWIRAUSAHA BAGI ANAK PANTI ASUHAN AL KAMILAH
}

\author{
Johan Syahbrudin ${ }^{1}$, Eka Rima Prasetya ${ }^{2}$, Siti Mundiroh $^{3}$, Samsul Marpitasa ${ }^{4}$, Prima Sadewa ${ }^{5}$, \\ ${ }^{1}$ Prodi Teknik Informatika, Fakultas Teknik, Universitas Pamulang* \\ 2,3,4,5 Prodi Akuntansi S1, Fakultas Ekonomi, Universitas Pamulang \\ *dosen01263@unpam.ac.id
}

\begin{abstract}
Abstrak
Masalah prioritas yang dihadapi oleh mitra yang dalam hal ini anak panti asuhan Al Kamilah yaitu rendahnya kemampuan berbahasa inggris, berhitung, dan minat berwirausaha. Pengabdian ini bertujuan untuk meningkatkan minat berwirausaha anak-anak melalui pendekatan pembelajaran bahasa inggris dan berhitung berbasis kewirausahaan. Metode yang digunakan dalam pengabdian ini adalah dengan memberikan pelatihan/pembelajaran bahasa inggris dan berhitung melalui pendekatan kewirausahaan yang dilakukan secara berkala selama 1 bulan dan bergantian (antara materi berhitung dan bahasa inggris). Pemberian pelatihan/pembelajaran bahasa inggris dan berhitung melalui pendekatan kewirausahaan yang dilakukan secara berkala selama 1 bulan terbukti efektif untuk meningkatkan minat berwirausaha anakanak Yayasan Al Kamilah, tetapi kurang efektif untuk meningkatkan kemampuan berbahasa inggris dan berhitung. Dan karena kemampuan awal berbahasa Inggris dan berhitung anak-anak tersebut yang masih sangat kurang, maka sebaiknya kegiatan pengabdian ini dapat dilanjutkan dalam waktu yang lebih lama lagi.
\end{abstract}

Kata Kunci: Motivasi Berwirausaha; Pembelajaran Berbasis Kewirausahaan; Panti Asuhan Al-Kamilah

\section{Abstract}

The priority problem faced by partners, in this case the children of the Al Kamilah orphanage, is the low ability to speak English, count, and interest in entrepreneurship. This service aims to increase children's entrepreneurial interest through approaches to learning English and entrepreneurship-based arithmetic. The method used in this service is to provide training / learning and English arithmetic through an entrepreneurial approach that is carried out periodically for 1 month and alternates (between numeracy material and English). The provision of training / learning English and arithmetic through an entrepreneurial approach that is conducted regularly for 1 month has proven to be effective in increasing the entrepreneurial interests of the children of the Al Kamilah Foundation, but is less effective in improving English language skills and numeracy. And because children's English skills and early arithmetic are still lacking, it is better that these community service activities can be continued for longer.

Keywords: Entrepreneur Motivation; Entrepreneurship Based Learning; Al-Kamilah Orphanage 


\section{PENDAHULUAN}

Dewasa ini, pendidikan kewirausahaan menjadi penting untuk diperkenalkan, baik pada negara maju maupun negara berkembang (Ozaralli \& Rivenburgh, 2016). Dan di Indonesia sendiri jumlah wirausahanya baru 1,5\% dari sekitar 252 juta penduduk, di mana fenomena ini terjadi karena masih rendahnya motivasi dan minat masyarakat Indonesia (Primandaru, 2017).

Oleh karenanya, penumbuhan / peningkatan motivasi / minat berwirausaha sejak dini sangat diperlukan untuk mengahadapi era pasar bebas saat ini. Karena motivasi berwirausaha berpengaruh positif terhadap minat berwirausaha (Mahanani \& Sari, 2018). Hal ini sejalan dengan temuan (Wijayangka, Kartawinata, \& Novrianto, 2018) di mana motivasi berwirausaha juga berpengaruh positif secara signifikan terhadap minat berwirausaha. Sehingga motivasi berwirausaha merupakan salah satu pendorong tumbuh kembangnya jiwa wirausaha seseorang, di mana salah satu motivasi yang paling dibutuhkan pelaku usaha adalah keinginannya untuk terus belajar dan menambah keterampilan.

Dan menilik pada salah satu permasalahan anak-anak yang menetap di yayasan Al-Kamilah khususnya yang berlokasi di Jl. Serua Raya No 3, Serua, Kec. Bojongsari, Kota Depok yaitu berkaitan dengan pengembangan potensi dan keahlian dalam berwirausaha dan membuka lapangan kerja. Di mana anak-anak dalam yayasan tersebut ada yang sebelumnya tidak sekolah, ia diminta oleh orang tuanya untuk bekerja di jalanan. Tentu hal ini memberikan banyak dampak negatif, di mana ia tidak mendapat pendidikan di sekolah, dilatih hanya untuk meminta tanpa tahu bagaimana berwirausaha, dan lain sebagainya.

Sehingga perlu adanya pembelajaran berbasis kewirausahaan yang menerapkan prinsip-prinsip dan metodologi ke arah aplikasi kewirausahaan melalui kreatifitas dan inovasi. Dengan dibekali pengetahuan kewirausahaan yang memadai, diharapkan dapat memberikan manfaat yang lebih maksimal kepada anak-anak panti asuhan tersebut, terutama ketika telah memasuki dunia kerja.

Seperti hasil temuan (Mardetini, Jaenudin, Fatimah, Firmansyah, \& Amrina, 2017), di mana pemberian wawasan tentang kewirausahaan industri kreatif untuk usia produktif terbukti dapat meningkatkan pemahaman peserta pelatihan pada materi kewirausahaan industri kreatif, dengan peningkatan yang terjadi dari setiap peserta sangat beragam mulai dari yang tidak ada peningkatan, peningkatan rendah, sedang dan bahkan ada yang mengalami peningkatan yang tinggi.

Dan karena sekarang sudah memasuki era pasar bebas, tentu penguasaan 
kewirausahaan perlu diimbangi dengan kemampuan berbahasa inggris agar bisa bersaing di dunia internasional. Dengan menguasai bahasa Inggris, kita akan lebih mudah untuk mencari informasi. Terlebih di internet banyak sekali ide-ide kreatif yang ditulis dalam bahasa Inggris. Jika kita menguasai bahasa Inggris, tentunya kita akan memahami ide-ide kreatif tersebut dengan lebih mudah. Setelah itu, kita bisa mencoba untuk mengaplikasikan ide tersebut pada usaha kita. Seperti yang kita tahu, ide unik atau menarik bisa membuat usaha kita berkembang cepat karena menarik minat banyak orang.

Selain membantu untuk menemukan ide kreatif, bahasa Inggris juga dapat digunakan untuk mengembangkan usaha. Seperti yang kita tahu, pebisnis biasanya ingin memiliki bisnis yang berkembang. Saat bisnis sudah benar-benar berkembang, maka diperlukan promosi lebih lanjut untuk mengenalkan bisnis kita ke pasar internasional. Dengan menguasai bahasa Inggris, kita bisa melakukan promosi tanpa harus kebingungan. Maksudnya, kita bisa menggunakan bahasa Inggris untuk mempromosikan bisnis kita. Dengan begitu, mengenalkan bisnis kita pada siapa pun tidak akan mengalami hambatan saat kita menguasai bahasa Inggris. Tak hanya itu saja, kita pun bisa bekerja sama dengan pebisnis lain yang ada di luar negeri. Dengan menguasai bahasa Inggris, kita tidak perlu bingung saat bertemu dengan pebisnis dari luar negeri. Meskipun kita bisa mempekerjakan penerjemah, namun menguasai bahasa Inggris jauh lebih penting karena bisa membuat kita terhindar dari penipuan. Dan masih banyak manfaat lainnya dari penguasaan bahasa Inggris.

Selain penguasaan bahasa Inggris, kemampuan berhitung juga sangat diperlukan jika ingin berwirausaha. Matematika dalam kehidupan bisnis digunakan sebagai media atau alat untuk menyederhanakan penyajian dan pemahaman masalah dimana dengan penggunaan bahasa matematika, masalah-masalah yang ada dalam dunia bisnis dapat menjadi lebih sederhana untuk disajikan, dipahami, dianalisis, dan dipecahkan. Konsep-konsep matematika sangat penting dalam dunia bisnis untuk menganalisis suatu permasalahan serta berfungsi untuk merumuskan hubungan antarvariabel tersebut dalam bentuk persamaan matematis, agar dapat diuji keberlakuannya secara empiris.

Jadi, agar anak-anak dalam panti memiliki bekal untuk masa depannya, perlu adanya pembekalan bahasa inggris, berhitung, dan juga berwirausaha, karena salah satu penyebab kemiskinan adalah 
produktivitas yang rendah, yang diakibatkan oleh pendidikan, keterampilan dan etos kerja yang rendah, sehingga berakibat pada pendapatan kecil, daya beli rendah, dan bermuara pada pemenuhan gizi yang kurang tercukupi, sehingga mengakibatkan kesehatan rendah.

Oleh karenanya, selain bagaimana mengembangkan potensi anak-anak ini dalam hal berhitung dan berbahasa inggris, tentu juga bagaimana mengaplikasikan dan memasarkan potensi dan keahlian yang dimilikinya dalam berwirausaha dan membuka lapangan kerja. Di sinilah peran pendekatan pembelajaran kewirausahaan diperlukan, sehingga diharapkan dapat memberikan manfaat yang lebih maksimal kepada anak-anak panti asuhan tersebut.

Jadi telah jelas bahwa kemampuan berbicara dalam Bahasa inggris menjadi penting dimiliki oleh anak-anak yang tinggal di yayasan tersebut, terutama untuk menyiapkan diri di era globalisasi saat ini terutama dalam dunia wirausaha. Karena bagaimanapun juga, kemampuan bahasa Inggris sangat mendukung seseorang yang berniat mendalami kemampuan berwirausaha (entrepreneurship) di era go international saat ini. Selain itu, meningkatkan kemampuan berhitung dan pemahaman matematika dasar anak-anak tentu sangat diperlukan dalam dunia usaha. Karena bagaimana mungkin seseorang pandai menghitung peluang bisnis tanpa kemampuan matematis yang memadai?

Oleh karena itu, usulan penyelesaian permasalahan/persoalan yang ditawarkan yaitu memberikan layanan pendidikan bahasa inggris (daily activities) dan matematika dasar menggunakan pendekatan pembelajaran berbasis kewirausahaan secara rutin selama 1 bulan, guna menumbuhkan semangat berwirausaha untuk menyongsong masa depan mereka dalam era pasar bebas saat ini.

\section{METODE}

Pelaksanaan pengabdian ini bertempat di Yayasan Al-Kamilah yang berlokasi di Jl. Serua Raya No 3, Serua, Kec. Bojongsari, Kota Depok, Jawa Barat 16517. Pengabdian ini bertujuan untuk meningkatkan minat berwirausaha anak panti asuhan Al Kamilah melalui pemberian layanan pendidikan bahasa inggris (daily activities) dan matematika dasar menggunakan pendekatan pembelajaran berbasis kewirausahaan.

Metode yang digunakan dalam Pengabdian Kepada Masyarakat ini adalah dengan memberikan pelatihan/pembelajaran dengan pendekata kewirausahaan yang dilakukan secara berkala selama 1 bulan (tanggal 16 Oktober 2019 sampai dengan 6 November 2019) kepada anak-anak yang 
menetap di yayasan Al-Kamilah. Karena penanaman nilai-nilai kewirausahaan ini dapat dilakukan dengan pendidikan kewirausahaan. Namun, proses penanaman nilai-nilai kewirausahaan kepada generasi muda ini tidak bisa dilakukan dalam waktu yang singkat, sehingga pendidikan kewirausahaan sangat penting diintegrasikan pada semua jenjang pendidikan di Indonesia.

Pembelajaran atau pelatihan ini dilakukan secara kebersinambungan dan tidak dalam waktu singkat, karena untuk memiliki kemampuan berbicara yang memadai dan berhitung serta berwirausaha secara otomatis ketika melihat suatu peluang diperlukan latihan terus menerus. Dan setelah pelatihan, harapannya dapat menjadi modal yang penting bagi anak-anak untuk memperbaiki taraf hidup dan meraih masa depan yang lebih baik, dan dapat bersaing dalam perkembangan teknologi informasi yang sangat cepat.

Pembelajaran berbasis kewirausahaa yang dimaksud di sini dengan menerapkan konsep kewirausahaan yang meliputi: 1) Nilai-nilai kewirausahaan secara implisit dalam rencana pembelajaran seperti percaya diri, berorientasi pada tugas, pengambil resiko, orientasi ke masa depan, mandiri, kreatif, dan kerja keras, 2) narasumber mengimplementasikan rencana pembelajaran dalam mengintegrasikan nilai-nilai kewirausahaan melalui penugasan dan pemecahan masalah dalam pembelajaran bahasa inggris dasar dan matematika dasar, kemudian narasumber / guru melakukan penilaian dan evaluasi hasil pembelajaran atau pelatihan.

Pembelajaran/pelatihan ini dilakukan secara bergantian antara materi berhitung/ matematika dasar dan bahasa inggris. Dalam pertemuan pertama akan diberikan pelatihan berhitung/matematika dasar dengan pendekatan kewirausahaan yang rencananya diisi oleh Eka Rima Prasetya, S.Pd., M.Pd. Di akhir pelatihan yang pertama ini, pak Eka memberikan beberapa soal kepada peserta pelatihan sebagai acuan awal kemampuan berhitung. Pertemuan berikutnya dilanjutkan pembelajaran bahasa inggris yang juga dengan pendekatan kewirausahaan oleh Siti Mundiroh, S.S., M.Ak. Di akhir pertemuan, $\mathrm{Bu}$ Siti juga memberikan beberapa soal kepada peserta pelatihan sebagai acuan awal kemampuan berbahasa inggris. Pertemuan berikutnya yaitu pembelajaran bahasa inggris oleh Samsul Marpitasa, S.Pd., M.Pd. Pertemuan terakhir dilanjutkan dengan pembelajaran berhitung/matematika dasar oleh Prima Sadewa, S.Pd., M.Pd.

Jadi, dalam prakteknya, partisipasi mitra dalam pelaksanaan program yaitu sebagai peserta pembelajaran/pelatihan dengan tugas-tugas di antaranya: mengikuti 
pembelajaran secara sungguh-sungguh dan menyeluruh, melaksanakan tugas-tugas yang diberikan, dan bersedia memberikan feed back terkait pembelajaran yang diberikan. Dan bagi narasumber tentu merencanakan pembelajaran, melakukan pembelajaran, dan mengevauasi hasil dari pembelajaran atau pelatihan yang telah dilakukan.

Setelah keempat narasumber memberikan pelatihan bahasa inggris dan matematika dengan pendekatan kewirausahaan, maka tim pengabdi memberi soal uji kompetenti kepada peserta pelatihan sebagai tolak ukur untuk mengetahui perkembangan kemampuan berbahasa inggris dan berhitung, serta mewawancarainya terkait minat berwirausaha untuk mengetahui seberapa besar pengaruh dari pendekatan pembelajaran berbasis kewirausahaan yang telah diterapkan. Sehingga evaluasi pelaksanaan program di antaranya mengetahui perkembangan kemampuan berbahasa inggris dan berhitung, serta minat atau motivasi untuk berwirausaha.

\section{HASIL DAN PEMBAHASAN}

Metode yang digunakan dalam Pengabdian Kepada Masyarakat ini adalah dengan memberikan pelatihan/pembelajaran berbahasa inggris dan berhitung dengan pendekata kewirausahaan yang dilakukan secara bergantian (antara materi berhitung dan bahasa inggris) dan berkala selama 1 bulan (tanggal 16 Oktober 2019 sampai dengan 6 November 2019) kepada anak-anak yang menetap di yayasan Al-Kamilah Depok.

Pemberian pelatihan/pembelajaran berbahasa inggris dan berhitung ini dikarenakan kemampuan anak-anak dalam kedua hal tersebut tergolong sangat rendah, hal itu terbukti dari hasil pretest di mana anak-anak masih merasa kesulitan dengan operasi bilangan sederhana, dan kurang familiar terhadap english in daily activities.

Penggunaan pendekata kewirausahaan juga didasarkan pada analaisis awal melalui wawancara, diketahui bahwa minat berwirausaha anak-anak tersebut tergolong rendah. Serta penggunaan metode secara bergantian (antara materi berhitung dan bahasa inggris) dimaksudkan agar peserta pelatihan tidak mudah bosan. Karena variasi mengajar menunjukan pengaruh terhadap motivasi belajar siswa (Royyan, 2017).

Setelah dilakukan pelatihan bahasa inggris dan berhitung berbasis kewirausahaan, peserta pelatihan diberi tes sederhana dan diwawancarai terkait minat berwirausaha. Dari hasil tes dan wawancara, kemampuan berbahasa inggris dan berhitung tidak meningkat signifikan, tetapi minat berwirausaha meningkat cukup signifikan. 
Tidak meningkatnya secara signifikan kemampuan berbahasa inggris dan berhitung ini karena lamanya pelatihan masih dirasa sangat sedikit melihat dari kemampuan awal pesertanya, di mana ada anak yang bahkan belum bisa membaca dan berhitung, tentu hal ini menjadi pekerjaan rumah bagi tim pengabdi. Karena bagaimana pun juga kemampuan awal berpengaruh signifikan terhadap hasil belajar bahasa Inggris (Setyowati, 2012).

Hasil berbeda terkait minat berwirausaha yang menunjukkan kenaikan signifikan tidak terlepas dari pendekatan pembelajaran berbasis kewirausahaan, seperti ketika pembelajaran matematika yang lebih menekankan pada perhitungan modal, laba, dan rugi. dan setelah itu, anak-anak peserta pelatihan ternyata baru faham bahwa perhitungan dalam wirausaha ternyata mudah, hal inilah yang meningkatkan minat mereka untuk berwirausaha. Hal ini sejalan dengan temuan (Aini, 2015) yang menyatakan bahwa pembelajaran kewirausahaan berpengaruh terhadap minat mahasiswa untuk menjadi wirausaha. Dan pembelajaran kewirausahaan memberikan pengaruh positif untuk menumbuhkan minat berwirausaha (Christianingrum \& Rosalina, 2017). Pun juga hasil temuan (Jailani, Fahrurrozi, \& Rizqi, 2017) di mana pembelajaran kewirausahaan memiliki peran penting dalam meningkatkan minat dan motivasi berwirausaha.

Berdasarkan temuan tersebut dapat disimpulkan bahwa pemberian pembelajaran bahasa inggris dan berhitung berbasis kewirausahaan yang dilakukan secara berkala selama 1 bulan terbukti efektif untuk meningkatkan minat berwirausaha anak-anak Yayasan Al Kamilah. Akan tetapi, karena kemampuan awal berbahasa inggris dan berhitung anak-anak tersebut yang masih sangat kurang dan bahkan ada yang belum bisa membaca, maka kegiatan pengabdian yang hanya 1 bulan masih dirasa sangat kurang untuk meningkatkan kemampuan berbahasa inggris dan berhitung, sehingga kegiatan ini dirasa perlu untuk dilanjutkan dalam waktu yang lebih lama lagi.

\section{KESIMPULAN}

Pemberian pelatihan/pembelajaran bahasa inggris dan berhitung melalui pendekatan kewirausahaan yang dilakukan secara berkala selama 1 bulan terbukti efektif untuk meningkatkan minat berwirausaha anak-anak Yayasan Al Kamilah. Akan tetapi, karena kemampuan berbahasa Inggris dan berhitung anak-anak tersebut yang masih sangat kurang, maka sebaiknya kegiatan pengabdian ini dapat dilanjutkan dalam waktu yang lebih lama lagi. 


\section{UCAPAN TERIMAKASIH}

Terima kasih yang sebesar-besarnya kami tujukan kepada pengurus dan adik-adik di yayasan Al-Kamilah khususnya yang berlokasi di Jl. Serua Raya No 3, Serua, Kec. Bojongsari, Kota Depok yang telah menyambut tim pengabdi dengan sangat baik dan bersedia meluangkan waktunya selama kegiatan.

\section{REFERENSI}

Aini, Y. (2015). Pengaruh Pembelajaran Kewirausahaan terhadap Minat Mahasisw UPP Berwirausaha. Jurnal Ilmiah Cano Ekonomos, 3(1), 69-78. https://doi.org/https://doi.org/10.5281/z enodo.571256

Christianingrum, \& Rosalina, E. (2017). Pengaruh Pembelajaran Kewirausahaan terhadap Motivasi Berwirausaha. Integrated Journal of Business and Economics (IJBE), 1(1), 45-55. https://doi.org/10.17509/strategic.v18i1. 17583

Jailani, H., Fahrurrozi, M., \& Rizqi, Y. A. (2017). Pengaruh Pembelajaran Kewirausahaan terhadap Minat dan Motivasi Berwirausaha Siswa di SMK Negeri 1 Selong Tahun Pelajaran 2016. JPEK, 1(1), 49-56.

Mahanani, E., \& Sari, B. (2018). FaktorFaktor yang Mempengaruhi Minat
Berwirausaha Mahasiswa Fakultas Ekonomi Universitas Persada Indonesia Y.A.I. Ikraith-Humaniora, 2(2), 31-40. Mardetini, E., Jaenudin, R., Fatimah, S., Firmansyah, \& Amrina, D. E. (2017). Peningkatan Pengetahuan dan Minat Berwirausaha pada Industri Kreatif di Kecamatan Pemulutan Ogan Ilir. Jurnal Pemberdayaan Masyarakat Madani (JPMM), $\quad$ l(2), 207-229. https://doi.org/10.21009/jpmm.001.2.05

Ozaralli, N., \& Rivenburgh, N. K. (2016). Entrepreneurial intention: antecedents to entrepreneurial behavior in the U.S.A. and Turkey. Journal of Global Entrepreneurship Research, 6(3), 1-32. https://doi.org/10.1186/s40497-0160047-X

Primandaru, N. (2017). Analisis FaktorFaktor yang Berpengaruh pada Minat Berwirausaha Mahasiswa. Jurnal Economia, $\quad$ 13(1), 68-78. https://doi.org/10.21831/economia.v13i 1.13276

Royyan, M. I. (2017). Pengaruh Keterampilan Mengadakan Variasi Mengajar terhadap Motivasi Belajar Siswa pada Mata Pelajaran Sejarah Kebudayaan Islam Kelas VII MTs Ma'arif NU 1 Karanglewas Kabupaten Banyumas ([Skripsi]). Purwokerto: IAIN Purwokerto. 
Setyowati, E. (2012). Faktor-faktor yang Berpengaruh terhadap Hasil Belajar Bahasa Inggris Siswa SMP di Yogyakarta ([Tesis]). Yogyakarta: Program Pascasarjana Universitas Negeri Yogyakarta.

Wijayangka, C., Kartawinata, B. R., \&

Novrianto, B. (2018). Pengaruh

Motivasi terhadap Minat Berwirausaha Mahasiswa Program Studi Administrasi Bisnis Universitas Telkom. ECo-Buss, 1(2), 73-79. 